\title{
The Determinants of Corporate Entrepreneurship for Firms in Adventure Tourism Sector in South Africa
}

\author{
Cleopas Chigamba \\ Department of Business Management, University of Fort Hare, \\ P. Bag X1314, Alice, 5700, South Africa \\ Email: cchigamba@ufh.ac.za \\ Ellen Chenesai Rungani \\ Department of Business Management, University of Fort Hare, \\ P. Bag X1314, Alice, 5700, South Africa \\ Email: erungani@ufh.ac.za

\section{Caroline Mudenda} \\ Department of Economics, University of Fort Hare, \\ P. Bag X1314, Alice, 5700, South Africa \\ Email:mudenda@gmail.com
}

Doi:10.5901/mjss.2014.v5n9p713

\begin{abstract}
The paper investigated the determinants of corporate entrepreneurship for firms in adventure tourism sector in the Eastern Cape Province of South Africa. The population for the study were firms registered with the Nelson Mandela Bay Tourism Portal (NMBT) (2012) and the Dirty Boot Adventure South Africa (2012). Convenience sampling method was used. Data was collected through the use of a self-administered questionnaire. For the purpose of data collection, one hundred and fourteen questions were identified through a thorough review of the literature (Burns \& Burns, 2008:454). Field (2005:636) Principal component analysis was used to reduce the one hundred and fourteen questions to twelve factors namely: flat organisational structure, management support for intrapreneurship, vision and strategic intent, rewards / reinforcement and sponsorship, innovativeness and creativity, multi-disciplined teamwork and diversity, entrepreneurial leadership, resources and time, strong customer orientation, continuous cross-functional learning, tolerance of risk, mistakes and failure and work discretion and discretionary time. Data was analysed using descriptive statistics, Pearson's correlation, T-test and ANOVA. Cohen's (d-value) was used to measure the effect size of differences for t-statistics Cohen (1988:38). The Cronbach's alpha was used to test the reliability of the scales. The results showed significant positive relationships between the twelve factors and corporate entrepreneurship. Recommendations included an integrated framework that could assist adventure tour operator to establish and sustain corporate entrepreneurship within this sector.
\end{abstract}

Keywords: Corporate Entrepreneurship, Adventure Tourism, intrapreneurship, Innovativeness

\section{Introduction and Background of the Study}

The role of entrepreneurship and innovation is increasingly viewed as imperative for businesses to sustain and improve their competitiveness (Informal Competitiveness Council, 2012:1), which is also evident in tourism businesses. Tourism has been acknowledged for the past decade as one of the leading driving forces for economic development in postapartheid South Africa (Nel \& Binns, 2002:189). The tourism industry plays a significant role in the economic profile of all the nine provinces within South Africa (Vivier, 2005:9) and is one of the top foreign exchange earners. At present tourism is seen as the fastest growing industry globally, with economies benefiting from its positive impact on employment creation, equitable distribution of wealth and the balance of payment (Viljoen \& Tlabela, 2006:6).

According to the World Travel and Tourism Council (2011) figures, tourism directly and indirectly constitutes approximately $7 \%$ of the Gross Domestic Products (GDP) and employment in South Africa as compared to a global estimate of between $8 \%$ and $9 \%$; these approximations indicate the potential for significant growth in international tourism and its immense contribution to GDP. South Africa's tourism industry provided jobs to more than 1.2 million people in 
2011, the number increased to 1.25 million in 2012 (South African embassy in Netherlands, 2011). Williams and Soutar (2005:248) state that, adventure tourism demand grew at around $15 \%$ in 2005 and it is expected to double the growth rate by 2015. Due to pressure on resources, increase in demand for new adventure activities and the risks associated with adventure tourism, firms are forced to venture into entrepreneurial activities.

Among the core reasons given for South Africa's slow economic growth by Benitez-Amado, Perez-Arostegui and Llorens-Montes (2010:559) is shortage of entrepreneurs. Corporate entrepreneurship (CE) is vital to firm survival and growth in the twenty first century. According to Franz and Kimberly (2006:809) corporate entrepreneurship is designed to revitalise a company's business by changing its competitive profile or by emphasising innovation through research and development, and the pursuit of new markets. Indeed, research has shown that intrapreneurship improves profitability, empowers employees, increases revenue streams and overall firm performance (Benitez-Amado et al., 2010:559). CE has long been recognised as a potentially viable means for promoting and sustaining corporate competitiveness while CE activities serve as a catalyst in the fortification of a competitive advantage for enterprise gain (Adonisi \& van Wyk, 2011:3048). Entrepreneurial Orientation improves performance through risk taking, innovativeness, autonomy, competitive aggressiveness and proactiveness.

Most established businesses are a result of entrepreneurial ideas and they seem to discontinue intrapreneurship due to scale, strategic orientation and innovative human capital. In addition risk aversion, entrepreneurial strategy, organisational culture, organisational structure, resource availability, reward systems, management support discourage CE (Hill, 2003:25; Salarzehi \& Forouharfar 2011:491-492). Moreover, CE has two primary aims: the pursuit of new venture opportunities and strategic renewal (Dess, Lumpkin, \& Eisner, 2008:422). Corporate new venture creation was labelled "intrapreneuring" by Gifford Pinchot (1985) because it refers to building entrepreneurial businesses within existing firms.

Given the background of the contribution of the tourism industry to South African economy, it was therefore important to investigate factors that promote $\mathrm{CE}$ and the barriers to $\mathrm{CE}$ in the adventure tourism sector. The study firstly investigated the level of CE activity for adventure tourism firms in the Eastern Cape Province. Firms with higher level of entrepreneurial activity are involved in $\mathrm{CE}$; therefore the study investigated the driving force towards $\mathrm{CE}$. Those with lower or nil $\mathrm{CE}$ activities are negative to $\mathrm{CE}$; therefore factors that discourage them were investigated.

According to Kroeger (2007:61) higher levels of change create higher levels of uncertainty causing the entire firm to involve employees from all hierarchical levels within the firm in the planning process to facilitate opportunity recognition, the firm's ability to respond to change and find new avenues. Innovation is greatly affected by both driving forces and barriers. Salavou (2005:309) agrees that innovation is often well thought-out to be a critical basis of strategic change especially within the business setting.

\section{Importance of the Study}

The motivation for this study emanated from the fact that one of the factors inhibiting sustainability, and competitiveness of adventure tourism firms in South Africa is the lack of pursuit for intrapreneurship (Nayeger \& Van Vuuren, 2005:30). The study makes the following contributions to the extant literature in the following ways. First, it broadens our understanding of how a firm's strategic orientation (in this case the entrepreneurial orientation) influences the entrepreneurial activity within the enterprise and hence the competitive positioning of the firm. A better understanding of some underlying entrepreneurial orientation dimensions that determine or enhance productivity is significant. Second, by considering the potential influences of entrepreneurial orientation as a set of behaviours exhibited by the entrepreneurs on firm productivity, a better understanding of how entrepreneurial orientation drives and is being implemented across the many functional activities within the firm is attained. The central argument lies in the fact that CE exists as a result of the driving forces in the internal and external environment of the business. Identifying and scaling the driving forces assist firms and employees to master the relevant aspects that spear head entrepreneurial activities to pursue new venture opportunities and strategic renewal (Dess \& Lumpkin, 2005:149).

\section{Objectives of the Research}

When it comes to firms in the adventure tourism sector, little is known about the relevant drivers to entrepreneurial orientation. Although sustainable competitive advantage is sought for the best, most firms strive to create a series of temporary competitive advantages (Alsos, Madsen, Borch, Ljunggren \& Brastad, 2007). Consequently, the study was designed to investigate the factors that promote the adoption of CE by adventure tourism firms in the Eastern Cape Province. The study empirically investigated the determinants of CE for adventure tourism firms in South Africa. 


\section{Literature Review}

The following sections (Section 4.1 and Section 4.2) present the evidence of supporting literature with regard to the research.

\subsection{Theoretical review}

Research on intrapreneurship had focused on the processes involved in aligning the firm's processes towards an innovative culture and how the behaviours of independent entrepreneurs within the enterprise can be adapted to the corporate environment. The study adopted the social cognitive theory to analyse the impact of the environment on human development while also placing responsibility on the individual to grow from within. A social cognitive view of corporate entrepreneurship provides that each person can transform and act entrepreneurially given the resources and support to develop his or her abilities (Goldsby, Kuratko, Hornsby, Houghton, \& Neck, 2006:21).

Social cognitive theory was pioneered by Bandura (1963) as a social learning theory. Bandura (1986:448) argue that social cognitive theory is based on the assumption that information provision alone is not adequate to change behaviour. The author postulates that, an individual's behaviour can only change if the skills to engage in the behaviour are inculcated. Moreover, individuals should be trained to be able to use these skills consistently and under difficult circumstances. Bandura (1989:72) argues that the adoption of values, standards and attributes is governed by a much broader and more dynamic social reality rather than competencies alone.

Furthermore, the study employed an Integrative Model of the CE process to ascertain the interactive nature of the process rather than the entrepreneur. Antoncic and Hisrich (2004:530) argue that intrapreneurship is multidimensional and relies on the successful interaction of several activities rather than events occurring in isolation. An integrative model of $\mathrm{CE}$ is built on the factors surrounding the process of entrepreneurial behaviour development. Belousova, Gailly, and Basso (2009:3) define entrepreneurial behaviour generally as the discovery, evaluation, and exploitation of entrepreneurial opportunities.

\subsection{Empirical review}

Present-day entrepreneurship research originated from the work of economist Joseph Schumpeter (1883-1950). As cited in Barringer and Bluedorn (2002:422) Schumpeter argued that the main agents of economic growth are the entrepreneurs who introduce new products, new methods of production, and other innovations that stimulate economic activity. Corporate entrepreneurship (CE) has been defined inconsistently, its conceptualisation emanates from different facets. CE can be referred to as; intrapreneurship and entrepreneurial orientation. Its purpose is to generate a stream of continuous innovation, strategic renewal, and corporate venturing activities to stimulate growth, profitability and competitive position (Morris, Covin \& Kuratko, 2008:215).

According to Kemelgor (2002:68) intrapreneurship is a firm-level phenomenon in which the firm has a serious commitment to both incremental and radical innovations. The author views incremental and radical innovations as strategically important to the competitiveness of the firm and tactically important to its operations and processes. Successful entrepreneurial firms are able to produce a stream of innovations, systematically and consistently (Herbert \& Brazeal, 2002:4). A firm's ability to increase its entrepreneurial behaviour is largely determined by the compatibility of its management practices with its entrepreneurial ambitions.

$\mathrm{CE}$ is a fundamental activity practised by enterprises in order to survive in the long term; it leads to superior performance and it can be seen as a means of promoting and sustaining enterprise's series of short term competitiveness which might result in sustainable competitive advantage. The dimensions of intrapreneurship encompasses; Autonomy, Innovativeness, Pro-activeness, Competitive Aggressiveness, and Risk-taking. Salarzehi and Forouharfar (2011:490) argue that for firms to become prosperous and successful, they must firstly identify general and idiosyncratic barriers to the enterprises. To understand these barriers we have to know factors that foster intrapreneurship and then to study the obstacles in the way of these factors that fosters intrapreneurship.

\subsubsection{Definition of Terms}

Entrepreneur: Zimmerer, Scarborough and Wilson (2008); Southiseng and Walsh (2010, 2011) postulates that an entrepreneur is one who creates a new business in the face of risk and uncertainty for the purpose of achieving profit and growth by identifying significant opportunities and assembling the necessary resources to capitalize on them. 
Entrepreneurship: Mutezo (2005:17) argue that there is no definite definition that can wholly and precisely define entrepreneurship as it involves a lot of aspects. Despite of the challenges in defining the concept, Kuratko and Hodgetts (2007:56) derive the definition of entrepreneurship from Muzyka (1995) which argued that "entrepreneurship is a process that takes place in diverse business environments, causing changes in the economic system through novel ideas brought about by individuals who respond to economic opportunities that create value for both those individuals and society".

Entrepreneurial Orientation: McGuinness (2008:8) defines entrepreneurial orientation (EO) as the process, practices, and decision making activities that lead to new entry.

Intrapreneuring: Intrapreneuring can be conceptualised as the creation of entrepreneurial new ventures both within and surrounding the firm. (Oosthuizen, 2012:12)

Corporate Entrepreneurship: According to Lumpkin and Dess (1996, 2001, 2003, 2004) CE refers to the extent where the entire business acts towards creating a new entry. (Entrepreneurship -- creation of a new entry inside and outside the business, EO -- the processes, practices, and decision-making activities that lead to new entry, and CE -- the entire business acts towards creating a new entry inside or around the existing business).

\subsubsection{Conceptual model of Corporate Entrepreneurship}

Figure 1.1 presents the conceptual model of CE designed to show the link between factors that make CE possible and factors that stimulate CE behaviour. Tolerance of risk, mistakes and failure involves the readiness to make resources available to exploit opportunities and launch projects with uncertain outcomes and tentative projected. The feasibility of intrapreneurship is evident on the availability of resources, which seems to be best portrayed by time availability. Rewards and reinforcement develop the motivation of individuals to engage in innovative, proactive and moderate risktaking behaviour. Organisational boundaries capture the encouragement and willingness of managers to facilitate CE activities within an enterprise. Encouraging $\mathrm{CE}$ activities is the degree to which employees are empowered and function autonomously in their jobs. A strong customer orientation paves the way to find alternative innovative avenues. Finally management support gives a supportive organisational structure that provides the administrative means by which ideas are appraised, selected and executed. Constraints to these factors are the barriers to intrapreneurship. Conducive environment that allow expression of ideas and proper interaction leads to autonomous creativity

Figure 1: Practicability and behavioural stimulating effect of $\mathrm{CE}$

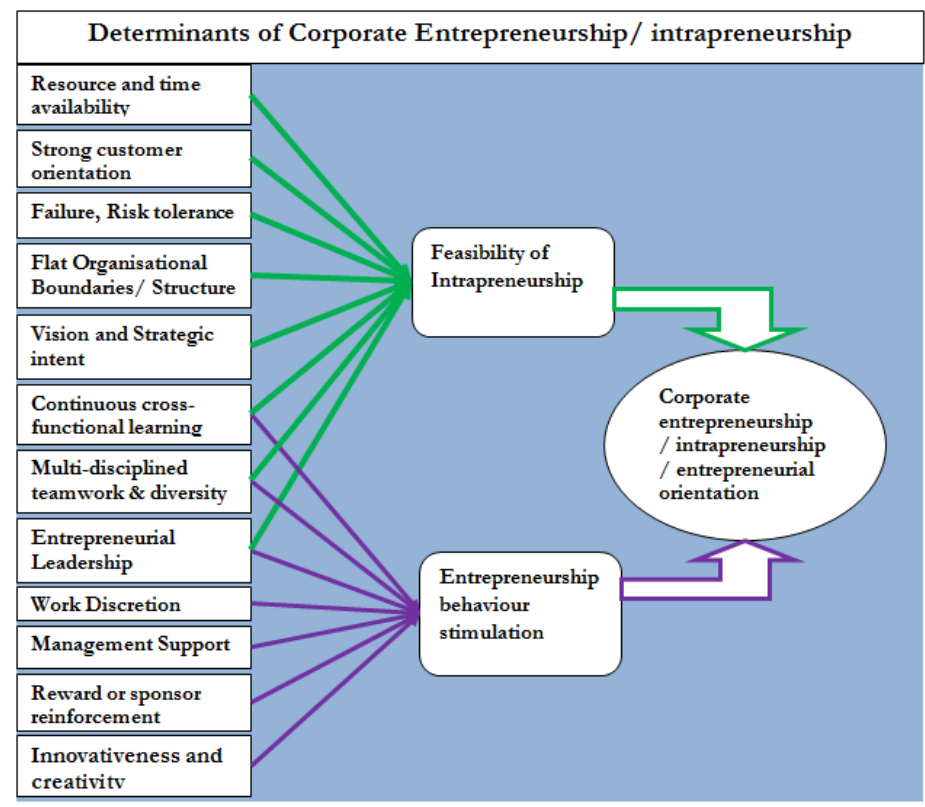

Source: Developed by author 


\section{Research Methodology}

\subsection{Population and sample}

Firms included in the survey were identified as those that are defined by the department of tourism as involved in outdoor adventures and adventure sports. The population and the sample frame of adventure tourism enterprises were therefore obtained from the Nelson Mandela Bay Tourism Portal (NMBT) and the Dirty Boot Adventure South Africa. The NMBT portal has about 216 members with approximately $40 \%$ falling into adventure category (Nelson Mandela Bay Tourism Portal, 2012). Dirty Boot Adventure South Africa has 45 adventure tour operators in the Eastern Cape \& Wild Coast Adventures region.

The population size from the selected region total is 135 . The study population consisted of all registered adventure tour operators in the Eastern Cape Province in South Africa. The study employed a convenience sampling method where a researcher selected the sample based on his or her personal judgement. One hundred and thirty five firms were contacted and 85 of them indicated their willingness to participate in this study and were shortlisted for the survey. For the purpose of the study the contact person in each firm selected the respondent to represent the company in the research.

\subsection{Measurement and Data Analysis}

The questionnaire used in the study was named CE Environment Assessment Questionnaire; the questionnaire consisted of a front page and a covering letter which included the guidelines to be followed in answering the questions. The questionnaire had three sections namely: demographical information, CE environment assessment and entrepreneurial characteristics. The questionnaire was developed from the initial questionnaire developed by Gifford Pinchot (1985), and modified by Oosthuizen (2006). Data analysis was done with the assistance of the Department of Statistics at the University of Fort Hare.

Data analysis was done using the Statistical Package for Social Sciences (SPSS) version 19.0 for Windows. The CE index was used to measure CE activity of adventure tourism firms through their scaling of the intensity of the adoption of CE dimensions (Johl \& Johl, 2008:953) and an exploratory factor analysis was conducted to uncover key dimensions in the CE Assessment Instrument CEAl (Hornsby et al., 2002).

In addition, exploratory factor analysis was also used to measure the construct validity of the measuring instrument. The Cronbach's alpha coefficient was used to measure reliability (Babbie \& Monton, 2002:81). Pearson correlation coefficients used to ascertain the relationship and the extent of the relationships between extracted construct. An independent T-test ( $p$-values) and their effect size Correlation ( $r$ ) and Cohen's ( $d$-values) were used to measure the differences and strength of differences. The differences were measured between demographic variables and entrepreneurial environment variables, perceptions of managers on their inclination to entrepreneurial orientation against the perception of their superiors and subordinates.

Findings were explained in form of arithmetic means and standard deviation of each construct. To assess the face validity and reliability of the measuring instruments, a pilot study was conducted on a selected sample of adventure tourism firms around Port Elizabeth: South Africa. Frequencies and percentages were calculated for the demographic variables; age, gender, race and highest educational qualifications.

\section{Results and Findings}

\subsection{Demographics}

From eighty five adventure tour operators who took part in the research, a total of one hundred and seventy employees were selected to represent the eighty five adventure tourism firms. Questionnaires were sent to them and ninety one questionnaires were returned. The response rate was $60.23 \%$. Male respondents evidently were the greater part of the respondents in the proportions of $61 \%$ male respondents and $39 \%$ female respondents. The age group $40-49$ years category dominated the respondents profile with a reading of 60 percent, followed by the second highest group (19.42 percent) with the ages in the range 30-39 years of age and the third highest group (14.56 percent) with the ages in the range 40 and 49 years old. The category of 60 and above year's age group is the least with only 0.97 percent. The purpose of the question was to compare the variations in means between categories of the demographic variable age with entrepreneurial climate and the entrepreneurial orientation variables 
Whites dominate the respondents profile with a reading of 47.57 percent, followed by the Blacks with 38.83 percent, the third highest group were Coloureds with 8.74 percent and the least being the Indians respondents profile with only 4.85 percent. The largest group of respondents (40.8 percent) obtained a Post graduate qualification and $34 \%$ percent of the respondents have a three year degree. Diplomas constitute 21.4 percent and National Certificated constitutes only 2.9 percent respectively. The operations division holds the majority of respondents 50 percent, 21.7 percent work in the Research and Development division and the third largest group is the Marketing and Financial services which hold 15.69 percent. The majority of respondents belong to the middle level of management (72.82 percent). Respondents were almost evenly distributed between the lower level and the top level management with 14.56 percent and 12.62 percent respectively.

\subsection{Entrepreneurial orientation attributes}

The results of self-assessment of entrepreneurial characteristics were sorted from the highest mean value to the lowest mean value. The characteristics opportunity driven and ability to take responsibility was ranked high in terms of its importance each with a arithmetic mean value of $(X=4.83)$. The characteristic team builder followed with mean $(X=$ 4.80), Highly inspirational $(X=4.75)$, Self-confidence $(X=4.74)$ and Ability to bring novel ideas $(X=4.68)$. All the characteristics obtained a high mean value, the following characteristics were valued the lowest by the respondents; Undertake personal sacrifice $(X=4.16)$, High energy level $(X=4.12)$, Low support needs $(X=4.12)$, Business knowledge $(X=3.96)$, Market awareness $(X=3.85)$ an Generosity $(X=3.68)$.

The results of Superior / Subordinate assessment on entrepreneurial characteristics reveal that the characteristics "highly inspirational" obtained the highest arithmetic mean value $(X=4.63)$. "Team builder" was ranked second highest (4.56) followed by "Low support needs" $(X=4.53)$, "Integrity and steadfastness" $(X=4.51)$, "Self- discipline" $(X=4.50)$, "Ability to adapt to change" $(X=4.49)$, "Self- confidence" $(X=4.46)$, "Internal locus of control" $(X=4.45)$ respectively. The following characteristics were valued the lowest by the respondents; "High level of Perseverance" $(X=3.86)$, "Tolerance for failure" ( $X=3.85)$, "Quick leaner" $(X=3.85)$, and "Undertake personal sacrifice" $(X=3.71)$.

\subsubsection{Comparisons between Self and Superior/Subordinate}

A paired sample t-test and the effect sizes analysis was done to compare the mean scores of respondents' perceptions of relative entrepreneurial characteristics measured relating to those of their superiors or subordinates. The effect size of associations between the self-assessment in terms of the entrepreneurial characteristics was measured by ( $r$ ) correlation coefficient and Cohen's (d) value. Ellis and Steyn (2003:51) define the effect size as a measure of practical significance independent of the sample.

Table 2 presents the evaluation of the comparison between the self and superior or subordinate assessment. The mean, standard deviation (Std. Dev), statistical significance $(\mathbf{p})$ and effect sizes $(\mathbf{r})$ and $(\mathbf{d})$ are given.

Table 2: Comparisons between self and superior / subordinate

\begin{tabular}{|c|c|c|c|c|c|c|c|}
\hline \multicolumn{8}{|c|}{ Entrepreneurial Orientation Traits } \\
\hline \multirow[t]{2}{*}{ Variable } & \multicolumn{2}{|c|}{ Self } & \multicolumn{2}{|c|}{$\begin{array}{l}\text { Superiorl } \\
\text { Subordinate }\end{array}$} & \multicolumn{3}{|c|}{ Comparison } \\
\hline & Mean & Std. Dev & Mean & Std. Dev & $\mathbf{P}$ & $\mathrm{r}$ & $\mathrm{d}$ \\
\hline Highly inspirational & 4.75 & .437 & 4.63 & .485 & .077 & 0.174 & 0.354 \\
\hline Need for achievement and growth & 4.43 & .651 & 4.33 & .833 & .404 & 0.083 & 0.166 \\
\hline Internal locus of control & 4.58 & .634 & 4.45 & .590 & .113 & 0.156 & 0.316 \\
\hline Ability to bring Novel ideas & 4.68 & .689 & 4.45 & .668 & $.014^{*}$ & 0.241 & 0.497 \\
\hline Opportunity driven & 4.83 & .373 & 4.35 & .789 & $.004^{*}$ & 0.498 & 1.148 \\
\hline High energy level & 4.12 & .351 & 4.36 & .765 & .053 & 0.190 & -0.387 \\
\hline Thriving on ambiguity and uncertainty & 4.47 & .607 & 4.36 & .712 & .266 & 0.110 & 0.221 \\
\hline Tolerance for failure & 4.64 & .624 & 3.85 & .797 & $.014^{*}$ & 0.428 & 0.948 \\
\hline Ability to take Responsibility & 4.83 & .373 & 4.44 & .750 & $.003^{*}$ & 0.391 & 0.848 \\
\hline Problem solving skills & 4.38 & .628 & 4.38 & .628 & .188 & 0.130 & 0.262 \\
\hline Calculated risk taking & 4.47 & .669 & 4.34 & .966 & .296 & 0.104 & 0.208 \\
\hline Self- confidence & 4.74 & .610 & 4.46 & .883 & $.007^{*}$ & 0.264 & 0.548 \\
\hline
\end{tabular}




\begin{tabular}{|c|c|c|c|c|c|c|c|}
\hline \multicolumn{8}{|c|}{ Entrepreneurial Orientation Traits } \\
\hline \multirow[t]{2}{*}{ Variable } & \multicolumn{2}{|c|}{ Self } & \multicolumn{2}{|c|}{$\begin{array}{c}\text { Superiorl } \\
\text { Subordinate }\end{array}$} & \multicolumn{3}{|c|}{ Comparison } \\
\hline & Mean & Std. Dev & Mean & Std. Dev & $\mathbf{P}$ & $\mathbf{r}$ & d \\
\hline Self- discipline & 4.66 & .534 & 4.50 & .624 & .053 & 0.199 & 0.406 \\
\hline Vision/ Open minded & 4.57 & .535 & 4.43 & .824 & .096 & 0.164 & 0.333 \\
\hline Team builder & 4.80 & .549 & 4.56 & .750 & .015 & 0.239 & 0.492 \\
\hline Integrity and steadfastness & 4.62 & .596 & 4.51 & .712 & .281 & 0.107 & 0.215 \\
\hline Ability to adapt to change & 4.61 & .598 & 4.49 & .803 & .174 & 0.134 & 0.271 \\
\hline Low support needs & 4.12 & .351 & 4.53 & .654 & .053 & 0.454 & -1.020 \\
\hline Good people judgement & 4.38 & .544 & 4.25 & .737 & .179 & 0.133 & 0.268 \\
\hline High Patience levels & 4.34 & .587 & 3.99 & .755 & .155 & 0.140 & 0.283 \\
\hline Business knowledge & 3.96 & .839 & 3.96 & .839 & .164 & 0.137 & 0.278 \\
\hline Market awareness & 3.85 & .797 & 4.07 & .795 & .054 & 0.190 & 0.387 \\
\hline Generosity & 3.68 & .797 & 4.34 & .735 & .175 & 0.134 & 0.270 \\
\hline Balanced self-esteem \& development & 4.46 & .556 & 3.96 & .839 & $.044^{*}$ & 0.457 & 1.027 \\
\hline Belief in value for money & 4.46 & .520 & 3.92 & .977 & .068 & 0.194 & 0.396 \\
\hline Quick leaner & 4.56 & .518 & 3.85 & .797 & .000 & 0.633 & 1.637 \\
\hline Limited need for status and power & 4.65 & .499 & 4.26 & .727 & .067 & 0.357 & 0.764 \\
\hline Undertake personal sacrifice & 4.28 & .452 & 3.71 & .690 & .051 & 0.193 & 0.394 \\
\hline Highly creative and innovative & 4.52 & .502 & 3.92 & .977 & .064 & 0.434 & 0.962 \\
\hline Higher levels of Commitment & 4.44 & .605 & 4.07 & .795 & .063 & 0.336 & 0.714 \\
\hline Highly Determined & 4.59 & .513 & 4.34 & .735 & .155 & 0.273 & 0.568 \\
\hline High level of Perseverance & 4.44 & .518 & 3.86 & .849 & $.009^{*}$ & 0.256 & 0.529 \\
\hline
\end{tabular}

* Statistical significant at the $p=0.05$ level (2-tailed)

The results of the comparisons between Self-assessment and Superior / Subordinate assessment shown in Table 2 reveal that there are no statistically significant differences with respect to the entrepreneurial characteristics with a $p$ value less than 0.05 . Only eight factors prove to be statistically significant. These are; Ability to bring novel ideas $(p=$ $.014 ; r=0.174 ; d=0.354)$, Opportunity driven $(p=.004 ; r=0.498 ; d=1.148)$, Tolerance for failure $(p=.014 ; r=0.428 ; d$ $=0.948)$, Ability to take responsibility $(p=.003 ; r=0.391 ; d=0.848)$, Self- confidence $(p=.007 ; r=0.264 ; d=0.548)$, Balanced self-esteem \& development $(p=.044 ; r=0.457 ; d=1.027$ ), Quick leaner $p=.000 ; r=0.633 ; d=1.637$ ) and High level of perseverance $(p=.009 ; r=0.256 ; d=0.529)$. All eight factors show medium to large effect.

\subsection{Entrepreneurial environment determinants}

In order to reduce the amount of entrepreneurial orientation determinants into useful sections and manageable number of components, the principal component analysis was performed. Field (2005:636) provides a theoretical justification in the belief that the principal components of the exploratory factor analysis measuring perceived importance of factors would correlate with each other.

\section{Kaiser-Meyer-Olkin (KMO) and Bartlett's Test}

Burns and Burns (2008:454) suggest that the two tests, Bartlett's test of sphericity and the Kaiser-Meyer-Olkin measure of sampling adequacy were considered important in determining the appropriateness of the data for factor analysis. The results of Kaiser-Meyer-Olkin $(K M O)$ and Bartlett's Test $(B T S=492.073$; sig. $=0.001)$ showed that the data was fit for the purpose of factor analysis. BTS yielded a p-value smaller than 0.01 indicating that patterns of correlations are close and that factor analysis should yield consistent and reliable factors. Statistically, this explains that there are relationships between the variables and that they can be appropriately included in the factor analysis. The result of the Kaiser-Meyer-Olkin (KMO) measure of sampling adequacy was 0.764 . The results indicate that there are adequate items for each factor. The combination of the two tests supports the suitability of the factor analysis technique. 
Table 3: KMO and BTS

${ }^{*}$ Sig. at 0.05 (2-tailed)

\begin{tabular}{|c|c|}
\hline Variables & \\
\hline KMO & 0.764 \\
\hline BTS & 478.064 \\
\hline Sig. & $0.001^{*}$ \\
\hline
\end{tabular}

\subsubsection{Total variance explained}

Twelve factors with Eigenvalues greater than one account for $89.94 \%$ of the total variance. The twelve factors were further confirmed by the rotation sums of squared loading after Varimax rotation. The rule of factor analysis states that only factors that have Eigenvalues greater than one are relevant and should be retained (Davis, 2005:446). In addition, the rule provides that the higher the percentage of the total variance the greater the influence the factor has.

\subsubsection{Rotated Factor Loading and Cronbach`s Alpha}

One hundred and fourteen questions (items) were rotated to find their factor loading. From the total of one hundred and fourteen items, one hundred and nine items had factor loading 0.3 and were retained. Five items had factor loadings lower than 0.3 and were removed as suggested by Leech, Barrett and Morgan, (2005:13). Looking at the Table 4, one can see that Resources and time (Resources accessibility and time availability), had the highest factor loading with (18) factors out of one hundred and fourteen questionnaire items. Innovativeness and creativity, follows with (15) factors items. Rewards / Reinforcement and Sponsorship (13) items, Work discretion and discretionary time (11) factor items, both Vision and Strategic intent and Tolerance of risk, mistakes and failure have each (8) factor items respectively. Management Support for Intrapreneurship and Strong customer orientation have (7) items each. Both Flat organisational structure and Continuous cross-functional learning fall second from the least with each (6) items respectively. Multidisciplined teamwork and diversity and Entrepreneurial leadership have the least number of factors each with (5) five questionnaire items respectively. All of the Chronbach's alpha coefficient level's tested were greater than 0.7, this indicated higher reliability of the survey instrument.

Table 4: Rotated factor loading and cronbach's alpha

\begin{tabular}{|c|l|c|c|c|c|c|}
\hline \multicolumn{8}{|c|}{ Constructs of corporate entrepreneurial environment } \\
\hline & & No. Fact & Mean & Std. Dev & Eigen value & Cronbach's Alpha \\
\hline 1 & Resources and time & 18 & 3.86 & 0.910 & 30.29 & 0.970 \\
\hline 2 & Innovativeness and creativity & 15 & 3.99 & 0.885 & 24.36 & 0.968 \\
\hline 3 & Rewards/Reinforcement and Sponsorship & 13 & 4.04 & 0.817 & 10.17 & 0.966 \\
\hline 4 & Work discretion and discretionary time & 11 & 3.77 & 0.852 & 9.74 & 0.971 \\
\hline 5 & Vision and Strategic intent & 8 & 4.04 & 1.000 & 9.16 & 0.972 \\
\hline 6 & Tolerance of risk, mistakes and failure & 8 & 3.81 & 0.864 & 8.62 & 0.969 \\
\hline 7 & Management Support for Intrapreneurship & 7 & 4.19 & 0.758 & 7.80 & 0.971 \\
\hline 8 & Strong customer orientation & 7 & 3.85 & 1.052 & 5.83 & 0.970 \\
\hline 9 & Flat organisational structure & 6 & 4.36 & 0.641 & 4.50 & 0.892 \\
\hline 10 & Continuous cross-functional learning & 6 & 3.82 & 0.975 & 3.91 & 0.970 \\
\hline 11 & Multi-disciplined teamwork and diversity & 5 & 3.95 & 0.759 & 3.48 & 0.971 \\
\hline 12 & Entrepreneurial leadership & 5 & 3.89 & 0.881 & 2.85 & 0.971 \\
\hline
\end{tabular}

(Items with factors loading less than 0.300 were omitted)

The twelve factors which influence entrepreneurial orientation within adventure tourism firms are presented below in the order of their importance as indicated by their contribution to the percentage of total variance. Factor one consists of eighteen items and was labelled as resources and time. The Eigen value for the factor is 30.29 . Cronbach's alpha for the factor yielded a value of 0.970 indicating the reliability of the factor. Factor two includes fifteen items was labelled Innovativeness and creativity. The Eigenvalue for the factor is 24.36 . Cronbach's alpha for the factor yielded a value of 0.968 indicating the reliability of the factor. Factor three is made up of thirteen factors and was labelled 
Rewards/Reinforcement and Sponsorship. The Eigenvalue for the factor is 10.17. Cronbach's alpha for the factor yielded a value of 0.966 indicating the reliability of the factor. Factor four consists of eleven items and was labelled as Work discretion and discretionary time. The Eigenvalue for the factor is 9.74. Cronbach's alpha for the factor yielded a value of 0.971 indicating the reliability of the factor. Factor five is made up of eight items and was labelled as Vision and Strategic intent. The Eigenvalue for the factor is 9.16. Cronbach's alpha for the factor yielded a value of 0.972 indicating the reliability of the factor. Factor six was labelled Tolerance of risk, mistakes and failure. The Eigenvalue for the factor is 8.62. The factor consists of eight items. Cronbach's alpha for the factor yielded a value of 0.969 indicating the reliability of the factor. Factor seven was labelled Management Support for Intrapreneurship. The Eigenvalue for the factor is 7.80 . The factor is made up of seven items. Cronbach's alpha for the factor yielded a value of 0.971 indicating the reliability of the factor. Factor eight was labelled Strong customer orientation. The Eigenvalue for the factor is 5.83. The factor consists of seven items. Cronbach's alpha for the factor yielded a value of 0.970 indicating the reliability of the factor. Factor nine consists of six items and was labelled Flat organisational structure. The Eigenvalue for the factor is 4.50. Cronbach's alpha for the factor yielded a value of 0.892 indicating the reliability of the factor. Factor ten was labelled Continuous cross-functional learning. The Eigenvalue for the factor is 3.91. The factor consists of six items. Cronbach's alpha for the factor yielded a value of 0.970 indicating the reliability of the factor. Factor eleven consists of five items and was labelled Multi-disciplined teamwork and diversity. The Eigenvalue for the factor is 3.48 . Cronbach's alpha for the factor yielded a value of 0.971 indicating the reliability of the factor. Factor twelve was labelled Entrepreneurial leadership. The Eigenvalue for the factor is 2.85 . The factor includes five items. Cronbach's alpha for the factor yielded a value of 0.971 indicating the reliability of the factor.

\subsubsection{Results of the T-Test}

The results of measure of the sizes of associations reveal that there are significant differences in the mean scores of males and females with regard to the twelve factors except for the following factors; entrepreneurial leadership (large effect, $r=0.478 ; d=1.088$ ), innovativeness and creativity (large effect, $r=0.459 ; d=1.033$ ), flat organisational structure (large effect, $r=0.384 ; d=0.832$ ), multi-disciplined teamwork and diversity (large effect, $r=0.406 ; d=0.889$ ), and resources and time (large effect, $r=0.431 ; d=0.954$ ).

\subsubsection{Results of ANOVA}

The results of the ANOVA show that there are no significant differences in the mean scores with respect to the twelve extracted factors except for flat organisational structure and continuous cross-functional learning. The F-ratio for flat organisational structure $(F=19.021 ; p=.000)$ and Continuous cross-functional learning $(F=25.524 ; p=.000)$. Both $p$ values are less than $(<.05)$. This shows that the difference in the mean scores of the three management levels is statistically significant with regard to these two factors.

\section{Conclusions and Managerial Implications}

Entrepreneurial characteristics can be learnt, therefore employees should be shown how these characteristics are developed and how they can evaluate, and support each other. It attempts to suggest that entrepreneurial attributes should be discussed repeatedly during weekly meetings; possibly two to three characteristics per meeting. The management should create formal structures within the initiation programme that will integrate with everyday workings of employees in adventure tourism. As a result of advances in technology this training can be circulated through e-mails, newsletters and as desktop slogans. Having employees fully informed of these entrepreneurial characteristics can help to lay the foundation for the environment that could be conducive for the generation of creative ideas. Moreover by unlocking the creative potential for establishing a CE environment for employees, many more new creative ideas may emerge. Employees understanding of entrepreneurial characteristics can help them to fully understand the actual drivers of CE and ultimately act towards maintaining a higher level of entrepreneurial activity.

Flat organisational structure allows free flow of information and instils a strong sense of belonging. Even though these structures allow open communication, managers should ensure establishment of small business units and focus groups, to curb possible barriers to open communication. Management support for intrapreneurship should be encouraged at all levels of management within an organisation. Management support for intrapreneurship follow management's initiative to establish formal structures that monitors idea generation, development transformation and implementation towards innovation. Employees become motivated when their ideas are evaluated and acted upon with 
urgency. Creativity is not independent but it is encouraged by prioritising idea generation as a key performance indicator for both individuals and teams at all levels. Inter-organisational interaction and team building should be encouraged within adventure tourism firms. Teams should be given freedom of choice when deciding how the team will be managed. Teams should be given the freedom to choose their team members and set their own disciplinary rules that governs their actions. According to the findings of this study multi-disciplined teamwork and diversity is an important determinant of corporate entrepreneurship.

Adventure tourism firms are encouraged to practice entrepreneurially focused leadership. Opportunities are practically created in a very structured way. Therefore employees should be challenged to bring novel ideas and think in innovative ways. Adventure tour operators tend to give much emphasis on customer expectations therefore customer orientation should be the source of inspiration for entrepreneurs to stay ahead of competition. This tempts to argue that customers represent the source of novelty. As adventure tour events encompass life threatening activities, calculated risks are taken more often. Managers should make it clear to employees that risk-taking behaviour is encouraged and acceptable by the employee of the adventure tourism firm. Therefore we can be tempted to argue that adventure tourism firms provide room for autonomy and freedom to employees to explore new ideas, before seeking for permission. Adventure tourism is deemed to be more dynamic as compared to other forms of tourism; it is associated with unique, unusual and riskier explorations (Kyriakaki, Maroudas, \& Gouvis, 2004:11). As a result radical innovations become key to intensify customer satisfaction and ensuring their safety. In support, McFadzean, O'Loughlin and Shaw (2005:350) provide that the practice of CE has become an important practice for managers to escalate attention as the aptitude to create innovation. In view of this argument, it is very important for firms in the adventure tourism industry to inaugurate and sustain corporate entrepreneurship as a tool to establish innovative services and processes to sustain their competitive advantage.

\subsection{Limitations of the study}

South Africa has nine provinces. Out of the nine provinces the study was limited to Eastern Cape Province. The data was collected from respondents based on their perceptions. Because of the limitations pointed out, care should be exercised in the interpretation and the application of the results of this study and the generalisation of the findings to the whole of South Africa. The study also captures a specific single segment of the entire tourism industry; that is adventure tourism firms. The population for the study was only firms registered with Nelson Mandela Bay Tourism Portal (NMBT) and the Dirty Boot Adventure South Africa. This means that non-registered adventure tourism firms were not included in the survey.

\subsection{Areas for further study}

The study did not include a comparison for CE with other sectors in the tourism industry. For comparative purposes, future research could be simulated with a sampling frame composed of respondents from different sectors of tourism. Finally, this study did not include those factors in the external environment that stimulate or trigger CE outside adventure tourism.

\section{References}

Adonisi, M. \& van Wyk, R. (2011). An eight-factor solution for the corporate entrepreneurship assessment instrument. African Journal of Business Management, 5(8), 3047 - 3055.

Alsos, A. G., Madsen, E.L., Borch, O. J., Ljunggren, E. \& Brastad, B. (2007). Developing entrepreneurial orientation - the role of dynamic capabilities and intangible Resources. Entrepreneurship Theories and Practice, 1(1), 94-105

Antoncic, B. \& Hisrich, R. D. (2004). Corporate entrepreneurship contingencies and organisational wealth creation. Journal of Management Development, 23(6), 526-540.

Babbie, E. \& Monton, J. (2002). The practice of social research. Cape Town: Oxford University Press.

Barringer, B. R. \& Bluedorn, A. C. (2002). The relationship between corporate entrepreneurship and strategic management. Strategic Management Journal, 20, 421-444.

Benitez-Amado, J., Llorens-Montes, F. J. \& Perez-Arostegui, M. N. (2010). Information technology-enabled intrapreneurship culture and firm performance. Industrial Management and Data Systems, 110(4), 550-566.

Binns, T. \& Nel, E. (2002). Tourism as a local development strategy in South Africa. Geographical Journal, 168, 235-47

Burns, R. A. \& Burns, R. B. (2008). Business research methods and statistics using SPSS. London: SAGE Publications Ltd.

Cohen, J. (1988). Statistical power analysis for the behavioural sciences. Hillsdale, NJ: Erlbaum 
Dess, G. G. \& Lumpkin, G. T. (2005). The role of entrepreneurial orientation in stimulating effective corporate entrepreneurship. Academy of Management Executive, 19(1): 147-156

Dess, G. G., Lumpkin, G. T. \& Eisner, A. B. (2008). Strategic Management: Creating Competitive Advantage. New York: The McGrawHill Companies Inc.

Dirty Boot adventure South Africa. (2011). Eastern Cape \& Wild Coast Adventures. [Online] Available: http://www.dirtyboots.co.za/adventures/region/eastern-cape-wild-coast-adventures/ (April 11, 2012)

Field, A. (2005). Discovering statistics using SPSS. 2nd ed. London: Sage Publications.

Franz, W. K \& Kimberly, A. E. (2006). Corporate Entrepreneurship in Family Firms: A Family Perspective. Entrepreneurship Theory and Practice, 30(6), 810-830.

Goldsby, M. G., Kuratko. D. F., Hornsby, J. S. Houghton, J. D. Neck, C. P. (2006). Social Cognition and Corporate Entrepreneurship: A Framework for Enhancing the Role of Middle-Level Managers, International Journal of Leadership Studies, 2(1), 17-35

Herbert, T.T. \& Brazeal, D.V. (2002). The future of the corporation: corporate entrepreneurship on the fly. [Online] Available: http://www.thomas-legrain.com/wp-content/documents/intrapreneuriat/corporate-entrepreneurship.pdf (June 23, 2012)

Hill M. E. (2003). The development of an instrument to measure intrapreneurship: entrepreneurship within the corporate setting. Grahamstown: Rhodes University. (Dissertation - MA.)

Hornsby, J. S. \& Kuratko, D. (2002). Middle managers' perception of the internal environment for corporate entrepreneurship: assessing a measurement scale. Journal of Business Venturing, 17, 253-273.

Informal Competitiveness Council (ICC2012). (2012). Innovation as a driving force for entrepreneurship. [Online] Available: http://www.cy2012.eu/index.php/de/file//4vg+IDy2g72nxXo9+AUZw (August 02, 2012)

Johl, S. \& Johl, S. (2008). Development of a corporate entrepreneurship index-A study of FTSE 100 companies in the UK. AGSE 2008, 953-967.

Kemelgor, B.H. (2002). A comparative analysis of corporate entrepreneurial orientation between selected RMS in the Netherlands and the USA. Entrepreneurship and Regional Development, 14(1), 67-87.

Kroeger, J. W. (2007). Firm Performance as a Function of Entrepreneurial Orientation and Strategic Planning Practices. Thesis Cleveland State University. (Doctoral; Business Administration), 1-165.

Kroeger, J.W. (2007). Firm Performance as a Function of Entrepreneurial Orientation and Strategic Planning Practices. Thesis Cleveland State University. (Doctoral; Business Administration), 1-165.

Kyriakaki, A., Maroudas, L. \& Gouvis, D. (2004). A Community Approach to Mountain Adventure Tourism Development. An International Journal of Tourism and Hospitality Research, 5(1), 5-18.

Leech, N. L., Barrett, K. C. \& Morgan, G. A. (2005). SPSS for intermediate statistics, use and interpretation. New Jersey: Lawrence Erlbaum Associates Inc.

Mcfadzean, E., O'loughlln, A. \& Shaw, E. (2005). Corporate entrepreneurship and innovation part 1: the missing link. European journal of innovation management, 8(3), 350-372.

Morris, M. H., Kuratko, D. D. \& Covin, J. G. (2008). Corporate entrepreneurs and innovation. Mason, OH: South-Western.

Nayeger, T. \& Van Vuuren, J. J. (2005). An Analysis of Organisational strategy, structure and culture that supports corporate entrepreneurship in Established firms. SAJEMS NS, 209-238.

Nelson Mandela Bay Tourism Portal (NMBT). (2012). [Online] Available: http://www.nmbt.co.za/search/1/things_to_see_and_do ladventure_sports (May 15, 2012)

Oosthuizen, J.H. (2006). Conceptualising an Integrated Framework for Corporate Entrepreneurship. Retrieved May, 18, 2012, from [Online] Available: http://poseidon01.ssrn.com/delivery/id=2019676.pdf

Roberts-Lombard, M. (2002). Marketing Research - A South African Perspective. Cape Town: Oxford University Press.

Salarzehi, H. \& Forouharfar, A. (2011). Understanding barriers to intrapreneurship in work and social affairs governmental organisation (a case study in Iran). Interdisciplinary Journal of Contemporary Research in Business, 2(12), 490-504

Salavou, H. E. (2005). Exploring product innovativeness determinants in SMEs. Journal of Marketing Management, 21, $307-338$.

South African embassy in Netherlands. (2011) Tourism. Retrieved July, 07, 2011, from [Online] Available: http://www.southafrica.nl/tourism

Van Wyk, R. \& Adonisi, M. (2008). The role of entrepreneurial characteristics in predicting job satisfaction. South African Journal of Economic and Management Sciences, 11(4), 391-92.

Viljoen. J. \& Tlabela, K. (2006). Rural Tourism Development in South Africa: Trends and Challenges. Cape Town: HSRC Press.

Viviers, P. (2006). The economic contribution of tourism to selected provinces of South Africa. Thesis North-West University (M.Com. Tourism), 1-71.

Williams, P. \& Soutar, G.N. (2005). Customer value and tourist satisfaction: A multidimensional perspective. Australian and New Zealand Marketing Academy Conference, Fremantle, Australia, December, 129-138.

World Travel \& Tourism Council. (2011). Travel \& Tourism 2011. Retrieved February, 02, 2012, from [Online] Available: http://www.wttc.org/site_media/uploads/downloads/traveltourism2011.pdf 